\title{
Long-Distance Movements of Anadromous Dolly Varden between Alaska and the U.S.S.R.
} ALFRED L. DeCICCO ${ }^{1}$

(Received 27 November 1990; accepted in revised form 19 June 1991)

\begin{abstract}
Two anadromous Dolly Varden, tagged in the Wulik River, Alaska, during September 1988, were recaptured in the Anadyr River, U.S.S.R., one in August 1989 and one in August 1990. Two additional tag recoveries were made south of the Bering Strait, one near Savoonga on St. Lawrence Island, Alaska, and one near Egavik in Norton Sound, Alaska. The greatest distance traveled was $1690 \mathrm{~km}$. This is the first record of fish movement between freshwaters of Alaska and the U.S.S.R. and the longest documented movement of a Dolly Varden or Arctic char.

Key words: Dolly Varden, Salvelinus malma, movements, U.S.S.R., Alaska
\end{abstract}

RÉSUMÉ. Deux Dolly Varden potamotoques étiquetés dans la rivière Wulik en Alaska au cours du mois de septembre 1988 ont été recapturés dans le fleuve Anadyr, en Union soviétique, l'un en août 1989 et l'autre en août 1990. Deux autres captures de poissons étiquetés ont eu lieu au sud du détroit de Béring, l'une près de Savoonga sur l'île Saint Lawrence en Alaska et l'autre près d'Egavik dans Norton Sound en Alaska. La distance maximale parcourue était de $1690 \mathrm{~km}$. Cela représente le premier cas documenté de migration de poissons entre les eaux douces de l'Alaska et de l'Union soviétique, ainsi que la migration documentee la plus longue d'un Dolly Varden ou omble chevalier.

Mots clés: Dolly Varden, Salvelinus malma, migration, Union soviétique, Alaska

Traduit pour le journal par Nésida Loyer. Движение По Большому Расстоянию Анадромных Малем (Salvelinus malma) Между Аляской и Советским
Союзом

Две анадромные мальмы, мечены в реке Улик, Аляска в сентябре 1988 возвращены в реке Анадыре, СССР. Рыбы тоже еще раз пойманы к югу от Берингого пролива близко от Савунги на острове Святого Лаврентия (St. Lawrence Island) и близко от Эгавика в заливе Нортон, Аляска. Самое большое попутешествовавшое расстояние - 1690 км. Эта работа первая запись движения малем между Аляской и Советским Союзом, и самое большое зарегистрированное расстояние или для малем или для обыкновенных гольца.

Важнейшие слова: американский голец, Salvelinus malma, движение, Аляска

\section{INTRODUCTION}

Movement studies of Dolly Varden, Salvelinus malma, and the closely related Arctic char, Salvelinus alpinus, have been confined mainly to freshwater and nearshore areas (Armstrong, 1974; Griffiths et al., 1975; Moore, 1975; Craig and McCart, 1976; Armstrong and Morrow, 1980; Craig and Haldorson, 1980; Johnson, 1980; Gyselman, 1984; Dempson and Green, 1985; Dempson and Kristofferson, 1987). Most available literature suggests that while anadromous char are at sea, they do not travel far offshore. Exceptions have been reported from Kodiak Island, Alaska, where a Dolly Varden tagged in the Buskin River was recaptured across Shelikof Strait in Dakavak Bay, a distance of $160 \mathrm{~km}$ (Sonnichsen $e t$ al., unpubl. data) and from Kamchatka, where Dolly Varden were caught as far as $420 \mathrm{~km}$ offshore (Mishima, 1975).

Long-distance movements are less uncommon. Jensen and Berg (1977) reported the longest distance traveled by an Arctic char tagged in the Vardnes River, Norway, as $940 \mathrm{~km}$. The fish was recaptured in the Tuloma River, U.S.S.R. Two other Arctic char were recaptured at distances of 500 and 400 $\mathrm{km}$ from the tagging location. Arctic char tagged at the outlet to Nauyuk Lake, Northwest Territories, Canada, have been recaptured at various locations in the Canadian archipelago (Gyselman, 1984) at distances of up to $500 \mathrm{~km}$ (Johnson, 1989). An Arctic char tagged in the Ekalluk River, N.W.T., in 1979 was recaptured three years later in Shepherd Bay, 550 $\mathrm{km}$ to the east, and the longest distance traveled by an Arctic char in northern Labordor was $250 \mathrm{~km}$ (Dempson and Kristofferson, 1987). In northwestern Alaska, a Dolly Varden tagged in a spawning area in the Noatak River system was recaptured at Point Hope one year later, a distance of $485 \mathrm{~km}$ (DeCicco, 1989a). On the Beaufort Sea coast of Alaska, Dolly Varden tagged in the Sagavanirktok River were recaptured up to $300 \mathrm{~km}$ away in Elson Lagoon, Alaska (Furniss, 1975). Another Dolly Varden tagged in the Lupine River, Alaska, was recaptured in the Firth River, Yukon, Canada, a distance of $350 \mathrm{~km}$ (Craig, 1977). The phenomenon of interdrainage exchange by Dolly Varden has also been observed in other Beaufort Sea drainages (Griffiths et al., 1975; Craig and McCart, 1976). Dempson and Kristofferson (1987) reported the movement of Arctic char between river drainages in Cambridge Bay, N.W.T., and northern Labrador, Canada. Sexually mature Dolly Varden in northwestern Alaska commonly overwinter in non-natal rivers during years in which they have been to sea (DeCicco, 1985, 1989a).

This paper presents data on movements of anadromous Dolly Varden that are of much greater distance than previously known, are not coastal in nature and indicate the first documented movement of Dolly Varden between freshwaters of Alaska and the Soviet Union. These data suggest that mixing of Dolly Varden stocks may occur over a wide geographic area throughout the northern Bering and southern Chukchi seas. 


\section{METHODS}

During September 1988, 4075 anadromous Dolly Varden (northern form, Behnke, 1980) were tagged in an overwintering area of the Wulik River in northwestern Alaska (Fig. 1). The purpose of the tagging was to estimate abundance of the overwintering population. Results of the abundance estimate are reported elsewhere (DeCicco, 1989b). Fish were captured with beach seines, measured for fork length and tagged with individually numbered Floy FD-67 internal anchor tags. Tagged fish ranged in fork length from 230 to $800 \mathrm{~mm}$. Dolly Varden that overwintered in the Wulik River began moving seaward on 13 June 1989 and continued to enter the sea through 3 July 1989. As of November 1991, 118 tags had been recovered: 93 from the Wulik River, 19 from Kotzebue Sound, 2 from the Noatak River, 1 from Norton Sound, 1 from St. Lawrence Island and 2 from the U.S.S.R.

\section{RESULTS AND DISCUSSION}

During August 1989, a Dolly Varden tagged in the Wulik River was recaptured in the Anadyr River, near Markovo in the U.S.S.R., $540 \mathrm{~km}$ from the mouth (Fig. 1). The fish traveled a distance of $1560 \mathrm{~km}$ during approximately 60 days, averaging $26 \mathrm{~km} \cdot \mathrm{day}^{-1}$. The tag was forwarded by Dr. N.P. Novikov of the Pacific Research Institute of Fisheries and Oceanographics in Vladivostock, U.S.S.R.

A second fish tagged in the Wulik River in 1988 was recovered from the Anadyr River in 1990. The fish was recaptured $670 \mathrm{~km}$ upstream from the mouth, having traveled a total distance of $1690 \mathrm{~km}$ in 14 months. The information was provided by Dr. Igor A. Chereshnev of the Institute of Biological Problems of the North in Magadan, U.S.S.R. (pers. comm.), although the tag has not yet been returned.

During August 1989, two tag recoveries were made indicating long-distance movements of Dolly Varden within Alaskan waters. Both fish moved south of the Bering Strait (Fig. 1). One was recaptured near Egavik in Norton Sound, $750 \mathrm{~km}$ along the Alaskan Coast, and the other near Savoonga on St. Lawrence Island, $180 \mathrm{~km}$ offshore from the Alaskan Coast and $530 \mathrm{~km}$ from the mouth of the Wulik River.

Dolly Varden tagged and released in the Kotzebue Sound and Chukchi Sea drainages of northwestern Alaska have shown complex movement patterns. Dolly Varden home to spawn, but stocks are mixed at sea and in overwintering areas. Interdrainage movement is common, with some fish tagged in all known spawning areas of the Noatak, Wulik and Kivalina rivers having been recaptured in the Wulik River overwintering area during years subsequent to spawning. Some

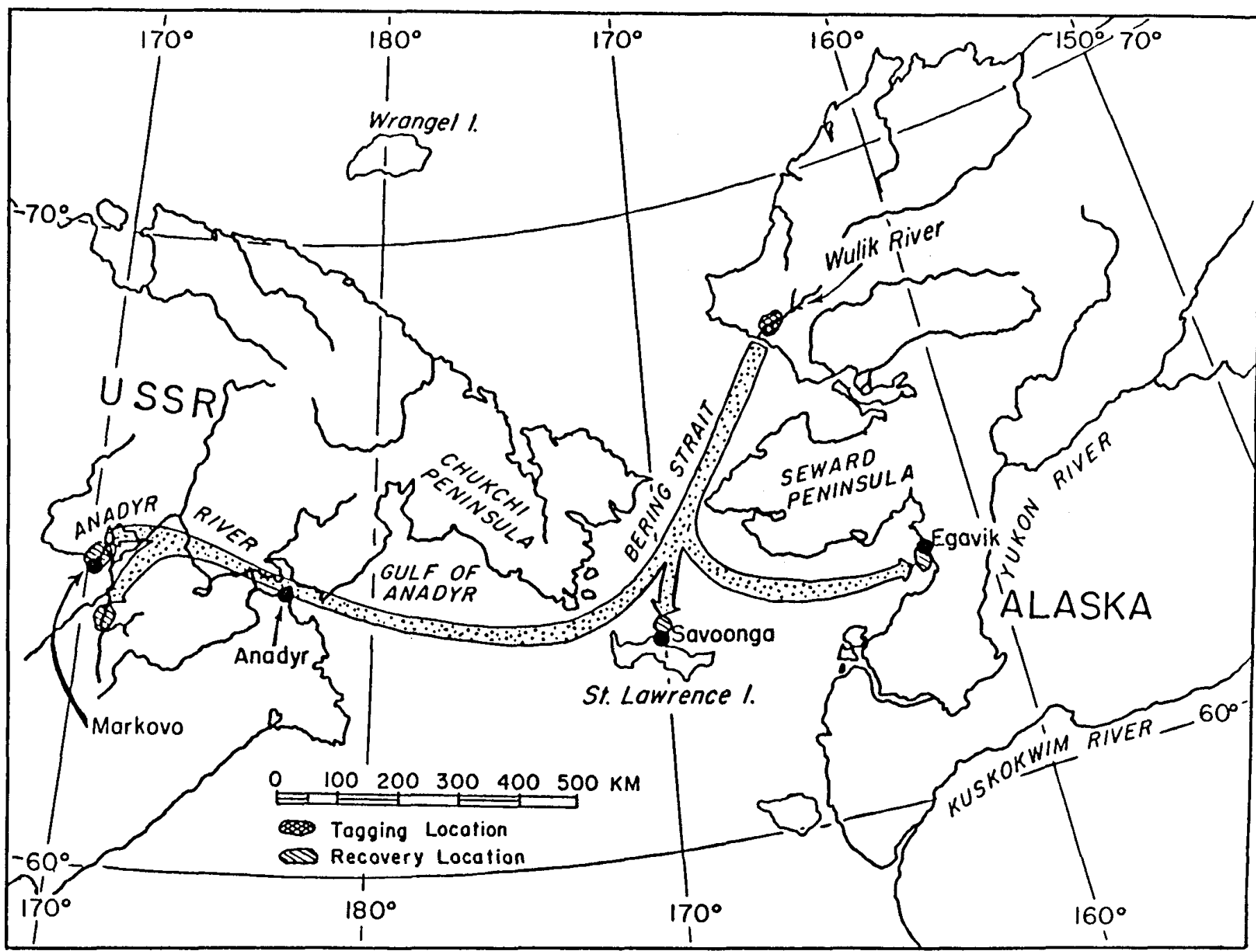

FIG. 1. Map showing long-distance movements of anadromous Dolly Varden with tagging and recapture locations. 
interdrainage movement has also been evident in immature anadromous Dolly Varden (DeCicco, 1985, 1989a).

The fish recovered in the Anadyr River in August 1989 was most likely of Anadyr stock that had spent the previous winter in the Wulik River and had subsequently migrated to the Anadyr River to spawn during fall 1989. Anadromous Dolly Varden are uncommon in the Markovo area but some migrate past to spawn in Anadyr River tributaries $100-150 \mathrm{~km}$ farther upstream (I.A. Chereshnev, pers. comm. 1990). There was no information provided on the sexual condition or size of this fish at capture; however, it was a female, $522 \mathrm{~mm}$ in fork length when tagged, a size at which some Dolly Varden in northwestern Alaska first reach sexual maturity. It was taken $540 \mathrm{~km}$ upstream from the river mouth, probably upstream of overwintering areas. This movement would be consistent with what has been observed in northwestern Alaska, where latesummer spawning occurs well upstream from areas used by nonspawners for overwintering. Based on the location of capture, $670 \mathrm{~km}$ upstream from the river mouth, the second recovery in the Anadyr River was also most likely a fish of Anadyr stock that was to spawn in 1990. The whereabouts and movements of this fish during the 14 months between tagging and recapture are unknown. The stock identity of the two fish recovered in Alaskan waters south of the Bering Strait in 1989 is also unknown. They could be Wulik River fish that had traveled into Norton Sound on a feeding migration, or they could be fish of Norton Sound origin that had spent the previous summer feeding in the Chukchi Sea and overwintered there.

Marine current flow through the Bering Strait during the open water period is in a northerly direction. Current speed just north of the Bering Strait between 16 July and 28 August 1987 ranged from $25 \mathrm{~cm} \cdot \mathrm{s}^{-1}$ to $85 \mathrm{~cm} \cdot \mathrm{s}^{-1}$. Wind-driven current reversals have been documented but typically occur after 1 September (Richard Tripp, unpubl. data). In northwestern Alaska, Dolly Varden usually undertake three to five ocean migrations before reaching sexual maturity. Since fish do not demonstrate fidelity to overwintering areas, it is during this period of their life history that stocks may become distributed over a wide geographic area. If fish tend to follow food sources that may be carried by marine currents in the northern Bering and southern Chukchi seas, the result could be mixed northerly distribution of stocks after several ocean migrations. Upon reaching sexual maturity, a homeward migration would result in movements indicated by these tag recoveries. Straying has been considered as an alternative explanation for the observed movements; however, it seems unlikely that directed movements of the magnitude and speed observed would result from reproductive straying.

Because of the close proximity of northwestern Alaska and the Chukotsk Peninsula, movements between these two areas might seem more likely than the movements indicated by the two Soviet tag recoveries. However, the Chukotsk Peninsula is sparsely populated and the chances of a tag being found and returned to appropriate authorities are probably small.

Gyselman (1984) suggested that $250 \mathrm{~km}$ was the limit to which an Arctic char could migrate in one summer. Rounsefell (1958) ranked Dolly Varden slightly higher than Arctic char in relative degree of anadromy among salmonids. Movement data presented here support the notion that northern form Dolly Varden are well adapted to the marine environment and may change existing concepts of the extent to which anadromous Dolly Varden may move while at sea. Dolly Varden are capable and may routinely undertake long-distance ocean movements that are not necessarily coastal in nature. Although the amount of stock mixing is unknown, these movements suggest that extensive mixing of stocks from wide geographic areas both at sea and in overwintering areas is possible.

\section{ACKNOWLEDGEMENTS}

The project from which these data were collected was partially funded by the U.S. Fish and Wildlife Service through the Federal Aid in Fish Restoration Act (16 U.S.C. 777-777K). Dr. N.P. Novikov of the Pacific Research Institute of Fisheries and Oceanographics in Vladivostok, U.S.S.R., and Dr. I.A. Chereshnev of the Institute of Biological Problems of the North in Magadan, U.S.S.R., forwarded information on tag recoveries. Dr. W. Arvey, P. Houton, E. Adey, O. Knox and J. Swan assisted in the initial tagging experiment. I thank Dr. W. Arvey, Dr. J. Clark and Dr. J. Reynolds for helpful comments on the manuscript; and Dr. L. Johnson, Dr. J.B. Dempson and Dr. D.R. Barton for critically reviewing the manuscript.

\section{REFERENCES}

ARMSTRONG, R.H. 1974. Migrations of anadromous Dolly Varden (Salvelinus malma) in southeastern Alaska. Journal of Fisheries Research Board of Canada 31:435-444.

ARMSTRONG, R.H., and MORROW, J.E. 1980. The Dolly Varden. In: Balon, E.K., ed. Charrs: Salmonid fishes of the genus Salvelinus. The Hague: Dr. W. Junk Publishers. 99-140.

BEHNKE, R.J. 1980. A systematic review of the genus Salvelinus. In: Balon, E.K., ed. Charrs: Salmonid fishes of the genus Salvelinus. The Hague: Dr. Junk Publishers. 441-480.

CRAIG, P.C. 1977. Ecological studies of anadromous and resident populations of arctic char in the Canning River drainage and adjacent coastal waters of the Beaufort Sea, Alaska. Arctic Gas Biological Report Series 41:1-116.

CRAIG, P.C., and HALDORSON, L. 1980. Beaufort Sea Barrier IslandLagoon Ecological Process Studies-Ecology of fishes in Simpson Lagoon and adjacent coastal waters, Beaufort Sea, Alaska. Final report, Research Unit 467. Boulder, Colorado: Outer Continental Shelf Environmental Assessment Program, NOAA.

CRAIG, P.C., and McCART, P.J. 1976. Fish use of nearshore coastal waters in the western Arctic: Emphasis on anadromous species. In: Hood, D.W., and Burrell, D.C., eds. Assessment of the arctic marine environment, selected topics. Occasional Publication No. 4. Fairbanks: Institute of Marine Science, University of Alaska. 361-380.

DeCICCO, A.L. 1985. Inventory and cataloging of sport fish and sport fish waters of western Alaska. Juneau: Alaska Department of Fish and Game. Federal Aid in Fish Restoration Annual Performance Report, 1984-1985. Project F-9-17, Job G-I-P-A, Vol 26:41-134.

1989a. Movements and spawning of adult Dolly Varden charr ( $S$. malma) in Chukchi Sea drainages of northwestern Alaska: Evidence for summer and fall spawning populations. Physiology and Ecology Japan, Special Vol. 1:229-238.

1989b. Northwest Alaska Dolly Varden study. Juneau: Alaska Department of Fish and Game. Fishery Data Series No. 90-8. 32 p.

DEMPSON, J.B., and GREEN, J.M. 1985. Life history of anadromous arctic charr, Salvelinus alpinus, in the Fraser River, northern Labrador. Canadian Journal of Zoology 63:315-324.

DEMPSON, J.B., and KRISTOFFERSON, A.H. 1987. Spatial and temporal aspects of the ocean migration of anadromous Arctic char. American Fisheries Society Symposium 1:340-357.

FURNISS, R.A. 1975. Inventory and cataloging of arctic waters. Juneau: Alaska Department of Fish and Game. Federal Aid in Fish Restoration Annual Performance Report Vol. 16. Project F-9-7, Job G-I-I. 47 p.

GRIFFITHS, W.B., CRAIG, P.C., WALDER, G., and MANN, G.J. 1975. Fisheries investigations in a coastal region of the Beaufort Sea (Nunaluk Lagoon, Yukon Territory). Arctic Gas Biological Report Series 34:1-219.

GYSELMAN, E.C. 1984. The seasonal movement of anadromous Arctic charr at Nauyuk Lake, Northwest Territories, Canada. In: Johnson, L., and Burns, B.L., eds. Proceedings of the Intemational Symposium on Arctic charr, Winnipeg, Manitoba, May 1981. Winnipeg: University of Manitoba Press. 575-578.

JENSEN, K.W., and BERG, M. 1977. Growth, mortality and migrations of the anadromous char, Salvelinus alpinus, L., in the Vardnes River, Troms, 
Northern Norway. Institute of Freshwater Research. Drottningholm Report 56:70-80.

JOHNSON, L. 1980. The Arctic charr, Salvelinus alpinus. In: Balon, E.K., ed. Salmonid fishes of the genus Salvelinus. The Hague: Dr. Junk Publishers. $15-97$.

1989. The anadromous Arctic charr, Salvelinus alpinus, of Nauyuk Lake, N.W.T., Canada. Physiology and Ecology Japan, Special Vol. 1:201-227.

MISHIMA, S. 1975. A biological study of the anadromous dolly varden Salvelinus malma (Walbaum) distributed in the west coast off Kamchatka in summer season 1972-1974. Bulletin of the Faculty of Fisheries, Hokkaido University 26:154-168.

MOORE, J.W. 1975. Distribution movements and mortality of anadromous arctic char, Salvelinus alpinus, in the Cumberland Sound area of Baffin Island. Journal of Fisheries Biology 7:339-348.

ROUNSEFELL, G.A. 1958. Anadromy in North American Salmonidae. U.S. Fish and Wildlife Service Bulletin 58:171-185. 